Article

\title{
A Note on Realistic Dividends in Actuarial Surplus Models
}

\author{
Benjamin Avanzi ${ }^{1,2, *}$, Vincent Tu ${ }^{1}$ and Bernard Wong ${ }^{1}$ \\ 1 School of Risk and Actuarial Studies, UNSW Australia Business School, UNSW Sydney, NSW 2052, \\ Australia; v.tu@unsw.edu.au (V.T.); bernard.wong@unsw.edu.au (B.W.) \\ 2 Département de Mathématiques et de Statistique, Université de Montréal, Montréal, QC H3T 1J4, Canada \\ * Correspondence: b.avanzi@unsw.edu.au; Tel.: +61-2-9385-0798
}

Academic Editor: Mogens Steffensen

Received: 3 August 2016; Accepted: 3 October 2016; Published: 20 October 2016

\begin{abstract}
Because of the profitable nature of risk businesses in the long term, de Finetti suggested that surplus models should allow for cash leakages, as otherwise the surplus would unrealistically grow (on average) to infinity. These leakages were interpreted as 'dividends'. Subsequent literature on actuarial surplus models with dividend distribution has mainly focussed on dividend strategies that either maximise the expected present value of dividends until ruin or lead to a probability of ruin that is less than one (see Albrecher and Thonhauser, Avanzi for reviews). An increasing number of papers are directly interested in modelling dividend policies that are consistent with actual practice in financial markets. In this short note, we review the corporate finance literature with the specific aim of fleshing out properties that dividend strategies should ideally satisfy, if one wants to model behaviour that is consistent with practice.
\end{abstract}

Keywords: surplus models; dividends; de Finetti; corporate finance

\section{Introduction}

From pioneer work on the modelling of an insurance company's surplus as a stochastic process in the first half of the 20th century (Lundberg [1], Cramér [2]), substantial theory exists to determine the stability of risky businesses. Criteria include the probability of ruin (a great classic is Asmussen and Albrecher [3]), but also the expected present value of dividends paid until ruin (see, for instance, Bühlmann [4]). For the model to make economic sense, the expected profit of the company is typically assumed to be positive. Since the probability of ruin monotonically decreases when the surplus increases, applying such a criterion should then lead companies to let their surplus grow to infinity. This issue was first raised by de Finetti [5], whose goal was to propose an alternative formulation that would be sufficiently realistic and tractable to "study the practical problems regarding risk and reinsurance". He explicitly allowed for surplus leakages, which were interpreted as dividends. When and how much dividends should be paid was determined such that the expected present value of dividends until ruin was maximised.

The stability criterion as suggested by de Finetti [5] presents itself some issues, which were summarised in Gerber [6] in the following way:

De Finetti's criterion has two principle disadvantages: (1) It is not directly concerned with the safety of the company. As a consequence, it generates optimal dividend policies that imply ultimate ruin with probability one. (2) It generates optimal strategies [...] that are hardly acceptable from a practical point of view.

Furthermore, in the introduction of their excellent review on dividend payout policy, Allen and Michaely [7] explain: 
"The challenge to financial economists has been to develop a payout policy framework where firms maximize shareholders' wealth and investors maximize utility. In such a framework payout policy would function in a way that is consistent with [empirical observations about dividend policy] and is not rejected by empirical tests."

The tension described here is that companies are generally considered to have a linear utility function (hence the objective of pure maximisation of dividends), but the decisions of investors (individuals) are often best modelled with more complex decision criteria. This tension cannot be resolved (at least not theoretically). The solution suggested by Allen and Michaely [7] is to simply look at what is observed in practice.

In this spirit, this note does not intend to add to the corporate finance literature, but rather summarise its findings in order to flesh out desirable properties. These often mean that one moves away from dividend maximisation, but this cannot be helped as explained above. Specifically, we aim to provide guidance beyond anecdotal knowledge of what is meant by "consistent with empirical observations about dividend policy". In so doing, this short note complements Albrecher and Thonhauser [8] and Avanzi [9], which did not discuss these issues.

In Section 2 we review the corporate finance literature, and in Section 3 we discuss some of the actuarial literature that is consistent with our observation, and comment of possible future developments.

Remark 1. Actuarial surplus models are increasingly relevant to modern risk management (see, e.g., Gerber and Loisel [10] who in particular also discussed the links between solvency requirements, coverage ratios, and dividend policies and their implications for practitioners). These models often provide interesting insights. While they still have some way to go to become directly applicable in practice (beyond insights), our firm belief is that we are getting closer to being able to build sufficiently realistic models that they can directly inform practice.

Remark 2. In this paper we assume that 'dividends' represent any diminution of surplus that is made to the profit of the company's owners according to the definition of 'aggregate payout' in (Allen and Michaely [7] p. 356). In particular, such payouts can take the form of either dividends (stricto sensu) or share repurchases; see also Section 2.1.

Whether surplus models in actuarial risk theory represent a cash or balance sheet (assets net of liabilities) approach is an unresolved debate. The approach should be carefully considered by the modeller, as some modelling choices make sense only in one particular context. For instance, interest on the surplus makes sense only in a cash approach, unless assets and liabilities are subject to identical interest rates (an arguably unrealistic assumption).

\section{Dividend Policy in the Corporate Finance Literature}

\subsection{Dividends and Repurchases as Payout Options}

As defined in Remark 2, we assume that payouts included in surplus models can be either dividends or repurchases. We discuss here the reasonableness of this assumption.

The literature on dividends and repurchases is abundant and divisive. Some studies (Bhattacharya [11], Miller and Rock [12]) imply that they are perfect substitutes, while others imply that they are not at all related (John and Williams [13], Allen, Bernardo, and Welch [14]). Executives surveyed by Brav, Graham, Harvey, and Michaely [15] seemed to believe that companies are indifferent between dividends and repurchases and that this had little impact on their clientele of investors.

From the point of view of the investor, capital gains (repurchases) usually attract less taxes than dividends. More generally, tax does not speak in favour of dividends, a 'puzzle' described by Black [16]. Using two theories of choice behaviour, Shefrin and Statman [17] show how dividends can still be preferred even though they are more taxed. A principal-agent analysis also supports the payment of dividends (Porta, Lopez-De-Silanes, Shleifer, and Vishny [18]). 
While there seems to be a historical trend from dividends to repurchases (Bagwell and Shoven [19], Fama and French [20], Grullon and Michaely [21]), (Allen and Michaely [7] p. 421) report that dividends and repurchases payouts when combined had remained fairly constant in the previous ten years. Lee and Suh [22] found that repurchases are often accompanied by increases in dividend payout. Furthermore, Denis and Osobov [23] examined data of six developed countries and could not find clear evidence that corporate dividend policies had materially changed.

We argue that in most cases, the mix of dividends and repurchases in the total payout is not an issue. It is not evident that the total payout is affected by this mix. Furthermore, before tax and for equivalent amounts, these lead to equivalent surplus diminutions. From a company's point of view, tax is not an issue. Transaction costs could be included in the model if they were arguably similar for both types of payouts.

From an investor's point of view, tax matters. However, companies (especially publicly held companies) don't necessarily know in which tax brackets their investors are. Unless this information is known and unless dividend and repurchases payouts are modeled separately, it is difficult to include tax in the model. Note though that taxes paid by companies (as modeled in Albrecher, Renaud, and Zhou [24] for instance) on their income are a different matter.

If dividends and repurchases are to be modeled separately, the following provides guidance. As companies are usually more committed to maintaining a stable dividend policy than a stable repurchasing policy (Lintner [25]), dividends are based on permanent earnings, whereas repurchases are related to both permanent and temporary shifts in earnings (Dittmar and Dittmar [26], Brav, Graham, Harvey, and Michaely [15], Lee and Suh [22]). Thus, ephemeral earnings are likely to be distributed in the form of repurchases, which are more flexible and noncommital. This is coherent with empirical observations indicating that repurchases are more volatile and more sensitive to economic conditions (Allen and Michaely [7] p. 349).

\subsection{Maturity of Companies}

Of course, part of the dividend puzzle (Black [16]) is that companies, if they have good investment opportunities, should arguably reinvest their cash rather than distribute it to shareholders.

Denis and Osobov [23] observe that the size, profitability and proportion of earned equity are all positively related with dividend payout volume. Growth opportunities have a mixed impact on dividend payout. Their results are consistent with the 'maturity hypothesis' (Grullon, Michaely, and Swaminathan [27]), according to which maturing firms, who have less investment opportunities and lower levels of risk, increase their dividend payout. Empirical observations suggest that the good news about risk prevails over the bad news about profitability (Allen and Michaely [7] p. 383).

Furthermore, companies that use exclusively repurchases (or don't pay out anything to shareholders) are likely to be small and less profitable (Lee and Suh [22]). Indeed, Denis and Osobov [23] attribute the disappearance of dividend payments mainly to newly listed firms.

In summary, both size (or maturity) and the debt-equity mix of companies have a definite impact on the volume (and type) of dividend payouts; see also Leland and Toft [28], Hilberink and Rogers [29], Décamps, Mariotti, Rochet, and Villeneuve [30], Décamps and Villeneuve [31] and the references therein for a rich discussion of the broader issue of optimal capital structure. Current models fail to model this behaviour in a direct way. Athough barrier strategies lead to dividends only when the surplus reaches a certain level, no consideration on the level of debt or maturity is taken from that moment.

\subsection{The Effect of Dividends on Shareholders' Wealth}

One justification for maximising dividends is that rational firms should aim at maximising shareholder's wealth. In our framework, dividends are all what shareholders will receive if we assume that shares have no residual value at the moment of ruin. However, the company may take a very 
long time to get ruined (if at all), and in reality it makes sense to take a more holistic approach to shareholder's wealth. In particular, the value of shares matters.

According to Miller and Modigliani [32], the dividend policy of a company is irrelevant to its value. However, we since then know that this holds true only under a number of assumptions that do not correspond to reality. Markets react positively to dividend payout increases and negatively to payout decreases—see Michaely, Thaler, and Womack [33] for dividends and Ikenberry, Lakonishok, and Vermaelen [34] for repurchases. Furthermore, larger changes lead to larger reactions, and decreases have more impact than increases (Allen and Michaely [7] p. 387). Lee and Suh [22] noticed that companies using exclusively repurchases experienced high stock return volatility.

\subsection{Dividend Smoothing}

The effect of dividends on share price explains why firms are very reluctant to cut dividends, even though some companies do not necessarily regard them as essential. If payout is changed, it is usually in the direction of an increase (Allen and Michaely [7] p. 349, p. 420). Since any increase is normally 'locked in', it makes sense for companies to try and smooth their dividend payout over time.

Results by Lintner [25] (later confirmed by Fama and Babiak [35]) concur. Stability of the payout is the primary concern. Indeed, companies start by setting their dividend policies, and then adjust all other policies accordingly. Furthermore, most companies seemed to have a target payout ratio. According to Shefrin and Statman [17] it makes sense for investors to prefer specific dividend payouts. Kumar [36] provides a theory of dividend smoothing.

The structure of ownership also has an impact. Michaely and Roberts [37] find that publicly held companies tend to have smooth, gradually increasing dividend and rare decreases, whereas the dividend policies of privately held firms is more volatile. Furthermore, the dividend payout of publicly held companies has little dependence on earnings.

\subsection{Signalling Models}

Some older studies argue that dividends are used as an ex-ante signal of future cash flow (such as Bhattacharya [11]). While dividends definitely convey information, this does not necessarily imply that they are used as signals (Miller and Rock [12]). Recent studies seem to indicate that this is indeed not the case. According to Brav, Graham, Harvey, and Michaely [15], the relation between dividends and earnings declined over the past 50 years. (Allen and Michaely [7] p. 396) summarise "the empirical evidence provides a strong prima facie case against the traditional dividend signaling models." - see also Denis and Osobov [23].

\subsection{The Case of Insurance Companies}

The main focus of actuarial risk theory is on insurance companies. Even if the results given above are fairly general, studies that focus exclusively on insurance companies have consistent results.

Concentrating on non-life insurers, Lee and Forbes [38] showed that the dividend policy had an impact on the market value of the firms. In a more general setting, Akhigbe, Borde, and Madura [39] also found that dividend increases resulted in significant share price increases. This impact was smaller for life insurers than for other types of insurers and industrial companies, but larger than for banks.

Dividend smoothing seems to be a wide-spread practice. Formisano [40] describes that earnings are saved into a surplus in order to smooth the dividend stream and in order to minimise changes. The pattern is then to 'buffer' the dividend stream in order to smooth out short run variability. Using the models of Lintner [25] and Fama and Babiak [35], Lee and Forbes [41] find that dividend payout is best explained by the prior year's dividend.

The nondecreasing property of the dividend flow seems to be even more important in the insurance industry. A source of the Financial Post (Tedesco [42]) reports "The last thing you do in this world if you're a financial institution is cut your dividend. [...] You make sure you've examined every possibility because nobody will forgive you." Indeed, a cut of Manulife's dividends as a result 
of the global financial crisis (resulting in annual savings of CAD 800 million) caused the stock price to decrease by $15 \%$.

In the case of mutuals, the company is not owned by investors, but by the policyholders. In this case, dividends can still be paid, but to the policyholders. Formisano [40] argues that a smoothing behaviour with a buffer should still be observed in the case of mutuals, but Zou, Yang, Wang, and $\mathrm{Zhu}$ [43] found (for non-life insurers) that mutuals were likely to pay less, and that they adjusted their payout more slowly than privately held firms.

\section{Implications for Actuarial Surplus Models}

The considerations outlined in the previous section can help risk theorists choose how to formulate their surplus with dividends, should their goal be to introduce some realistic features in them, in order to resolve the tension exposed in the introduction. There are two basic approaches: (i) restrict the set of admissible dividend strategies and still maximise their expected present value; or (ii) keep an unrestricted set of admissible dividend strategies but modify the objective. We discuss below some recent related developments.

We first provide a mathematical formulation for general actuarial surplus models. Define $U(t)$ as the surplus for the company and the modified surplus for the company (after distribution of dividends) is then

$$
X(t)=U(t)-L(t),
$$

where $L(t)$ represents the aggregate (non discounted) dividends received from time 0 to time $t$. Ruin occurs as soon as $X(t)$ becomes negative and ruin time is denoted as $\tau$. The formulation proposed by de Finetti [5] is then to maximise the the expected present value of dividends until ruin

$$
\mathbb{E}\left[\int_{0}^{\tau} e^{-\delta t} d L(t)\right]
$$

where $\delta$ represents the financial impatience.

In traditional admissible strategies, decision makers have the ability to issue dividends at any point in time. This assumption is inconsistent with observations from reality where dividends decisions are typically made periodically. This naturally leads to the consideration of strategies that issue dividend on discrete times. One such restricted set of admissible strategies studied in recent literature is known as periodic dividend strategies. Suppose that dividends paid at decision time $T_{j}$ is $\vartheta_{T_{j}}$ for $k=1,2,3, \ldots$, the optimal periodic dividend strategies seek to maximise the expected present value of dividends until ruin

$$
\mathbb{E}\left[\sum_{k=1}^{\infty} e^{-\delta T_{k}} \vartheta_{t_{k}} I_{\left\{T_{k} \leq \tau\right\}}\right] .
$$

The main challenge of studying periodic dividend strategies is to obtain tractable solutions, which is difficult even in basic surplus models. Some recent papers attempt to simplify the problem by relaxing model assumptions (e.g., Albrecher, Cheung, and Thonhauser [44]) or using techniques such as Erlangisation (e.g., Avanzi, Cheung, Wong, and Woo [45]) to obtain approximations to the solutions. Much work is still required.

A few authors also tried to address criticism voiced by Gerber [6] by creating strategies with realistic features. For example, it is arguably desirable for dividend strategies to distribute more dividends as surplus reaches high levels and one example of such strategies is known as multilayer dividend strategies (see, e.g., Albrecher and Hartinger [46], Lin and Sendova [47]). For example, dividend payments at time $t$ is given by

$$
d L(t)=a_{i} d t \quad \text { if } b_{i-1} \leq U(t)<b_{i},
$$


where $0=b_{0}<b_{1}<b_{2}<\ldots<b_{k-1}<b_{k}<\infty$ are the layers and dividends are paid out with density $a_{i}$ when the surplus $U(t)$ is in layer $i$ for $i=1,2,3, \ldots, k$. Dividends are issued at higher rates as surplus accumulates to higher levels, which potentially reflects profitability/maturity of the company (see Section 2.2). Motivated by the behaviour of some companies which pay regular and extraordinary dividends (see Section 2.1), Avanzi, Pérez, Wong, and Yamazaki [48] investigate an optimal two-layer strategy with transaction costs in spectrally positive Lévy processes.

Additionally, there is a whole stream of literature (see, e.g. Radner and Shepp [49], Højgaard and Taksar [50], Cadenillas, Choulli, Taksar, and Zhang [51] and references therein) that looks at the optimal joint investment, dividend, and reinsurance strategies, which relate to the discussion about optimal capital structure discussed in Section 2.2. Furthermore, papers such as Gerber and Shiu [52], Decamps, Schepper, and Goovaerts [53], Avanzi, Henriksen, and Wong [54] consider models with assets and liabilities that can scale up or down.

In a different light, irregular dividends (both in terms of amount and timing) is not an attractive feature of dividend strategies (see Section 2.4 for a review on dividend smoothing) and few authors tried to address this problem. Cheung, Dickson, and Drekic [55] found the threshold strategy that minimises the coefficient of variation of the present value of dividends until ruin

$$
C V(x ; b)=\frac{\sqrt{V_{2}(x ; b)-\left(V_{1}(x ; b)\right)^{2}}}{V_{1}(x ; b)}
$$

where $V_{1}(x ; b)$ and $V_{2}(x ; b)$ are the first and second moments of the present value of dividends, respectively. Albrecher and Cani [56] address the problem directly by specifying a dividend strategy that smooths dividend payouts over time. In the Cramér-Lundberg model, they consider dividends that are paid according to an affine strategy, i.e.

$$
d L(t)=(q X(t)+\beta) d t
$$

where $q>0$ and $\beta$ are constants. This idea was first introduced by Avanzi and Wong [57] in the Brownian risk model, and with $\beta=0$. Beyond smoothness, a non-decreasing payout strategy is yet to appear in the literature, but to find a non-trivial and tractable formulation is not easy.

Other authors address criticism of Gerber [6] by modifying the classical objective function. For example, Hubalek and Schachermayer [58] and Thonhauser and Albrecher [59] investigated the maximisation of expected utility of dividends

$$
\mathbb{E}\left[\int_{0}^{\tau} e^{-\delta t} u(l(t)) d t\right]
$$

where $u(\cdot)$ is a utility function applied to the dividend paid at time $t$ and where $d L(t)=l(t) d t$. However applying utility functions to a company is sometimes questioned, as it is not an individual with its own irrational will. It also does not resolve the tension mentioned in the introduction. Other interesting transformations have been considered in the literature, which carry interesting properties. For instance, Korn, Menkens, and Steffensen [60] consider worst-case optimisation in the case of large non-life insurers.

The main challenge of modifying current formulations of the objective is that it is often difficult to prove or disprove the existence of solutions under a new objective. One first has to propose an alternative objective and postulate strategies that may solve the optimisation problem (which does not guarantee solutions). Next one has to verify the global optimality of the obtained solutions (which presumes the solution exists). Simply put, there is no systematic method of creating objective functions that lead to a desired solution. For example, it is difficult to determine the objective under which mean reverting dividend strategies (proposed in Albrecher and Cani [56], Avanzi and Wong [57]) are the optimal solution and demonstrate its global dominance against all admissible strategies.

To summarise, the following could be considered when designing a dividend model: 
- the periodicity of dividend payments;

- the various range of possible distributions-for instance, standard dividends, which tend to be regular, as opposed to special dividends, which can be irregular (Section 2.1);

- the impact of the scale / maturity of the company, as well as its capital structure (Section 2.2);

- the regularity and smoothing of dividends (Section 2.4);

- the nondecreasing nature of dividends (also Section 2.6).

The actuarial literature we have reviewed in this section addresses some of those considerations. Hopefully this note can provide inspiration for further developments.

Acknowledgments: The authors are grateful to Mogens Steffensen for constructive comments on an earlier version of this article, and to reviewers for helpful comments and suggestions. This research was supported under Australian Research Council's Linkage Projects funding scheme (project number LP130100723). Furthermore, Benjamin Avanzi acknowledges financial support from an Australian School of Business Special Research Grant and Vincent Tu acknowledges financial support from an Australian Postgraduate Award and supplementary scholarships provided by the UNSW Australia Business School. The views expressed herein are those of the author and are not necessarily those of the supporting organisations.

Author Contributions: The main ideas of this research article were developed jointly between B.A., V.T. and B.W.; B.A. and B.W. performed the literature review, which was subsequently updated by V.T.; B.A. and V.T. wrote the paper.

Conflicts of Interest: The authors declare no conflict of interest.

\section{References}

1. Lundberg, F. Über die Theorie der Rückversicherung. In Transactions of the VIth International Congress of Actuaries; NULL: New York, NY, USA, 1909; Volume 1, pp. 877-948.

2. Cramér, H. Collective Risk Theory: A Survey of the Theory from the Point of View of the Theory of Stochastic Processes; Ab Nordiska Bokhandeln: Stockholm, Sweden, 1955.

3. Asmussen, S.; Albrecher, H. Ruin Probabilities, 2nd ed.; Advanced Series on Statistical Science and Applied Probability; World Scientific: Singapore, 2010; Volume 14.

4. Bühlmann, H. Mathematical Methods in Risk Theory; Springer: Berlin/Heidelberg, Germany, 1970.

5. De Finetti, B. Su un'impostazione alternativa della teoria collettiva del rischio. In Transactions of the XVth International Congress of Actuaries; NULL: New York, NY, USA, 1957; Volume 2, pp. 433-443.

6. Gerber, H.U. The Dilemma Between Dividends and Safety and a Generalization of the Lundberg-Cramér Formulas. Scand. Actuar. J. 1974, 1974, 46-57.

7. Allen, F.; Michaely, R. Payout Policy; Handbook of the Economics of Finance; Elsevier: Amsterdam, The Nertherland, 2003; Volume 1A, pp. 337-429.

8. Albrecher, H.; Thonhauser, S. Optimality results for dividend problems in insurance. RACSAM Revista Real Acad. Cienc. 2009, 100, 295-320.

9. Avanzi, B. Strategies for Dividend Distribution: A Review. N. Am. Actuar. J. 2009, 13, 217-251.

10. Gerber, H.U.; Loisel, S. Why risk theory should be of interest for insurance practitioners and risk managers nowadays. In Proceedings of the AFMATH Conference, Bruxelles, Belgium, 9-10 February 2012; pp. 17-21.

11. Bhattacharya, S. Imperfect Information, Dividend Policy, and "The Bird in the Hand" Fallacy. Bell J. Econ. 1979, 10, 259-270.

12. Miller, M.H.; Rock, K. Dividend Policy under Asymmetric Information. J. Financ. 1985, 40, 1031-1051.

13. John, K.; Williams, J. Dividends, dilution, and taxes: A signalling equilibrium. J. Financ. 1985, 40, $1053-1070$.

14. Allen, F.; Bernardo, A.E.; Welch, I. A Theory of Dividends Based on Tax Clienteles. J. Financ. 2000, 55, 2499-2536.

15. Brav, A.; Graham, J.R.; Harvey, C.R.; Michaely, R. Payout policy in the 21st century. J. Financ. Econ. 2005, 77, 483-527.

16. Black, F. The Dividend Puzzle. J. Portf. Manag. 1976, 2, 5-8.

17. Shefrin, H.M.; Statman, M. Explaining Investor Preference for Cash Dividends. J. Financ. Econ. 1984, 13, 253-282.

18. Porta, R.L.; Lopez-De-Silanes, F.; Shleifer, A.; Vishny, R.W. Agency Problems and Dividend Policies around the World. J. Financ. 2000, 55, 1-33. 
19. Bagwell, L.S.; Shoven, J.B. Cash Distributions to Shareholders. J. Econ. Perspect. 1989, 3, 129-140.

20. Fama, E.F.; French, K.R. Disappearing dividends: changing firm characteristics or lower propensity to pay? J. Financ. Econ. 2001, 60, 3-43.

21. Grullon, G.; Michaely, R. Dividends, Share Repurchases, and the Substitution Hypothesis. J. Financ. 2002, $57,1649-1684$.

22. Lee, B.S.; Suh, J. International Evidence on Corporate Payout Policy: Dividends vs. Share Repurchases. Available online: http://www.apjfs.org/conference/2007/report/332_suhjungwon.pdf (accessed on 17 October 2016).

23. Denis, D.J.; Osobov, I. Why do firms pay dividends? International evidence on the determinants of dividend policy. J. Financ. Econ. 2008, 89, 62-82.

24. Albrecher, H.; Renaud, J.F.; Zhou, X. A Lévy insurance risk process with tax. J. Appl. Probabil. 2008, 45, 363-375.

25. Lintner, J. Distribution of Incomes of Corporations Among Dividends, Retained Earnings, and Taxes. Am. Econ. Rev. 1956, 46, 97-113.

26. Dittmar, A.; Dittmar, R.F. Stock Repurchase Waves: An Explanation of the Trends in Aggregate Corporate Payout Policy. Available online: https:/ / papers.ssrn.com/sol3/papers.cfm?abstract_id=346548 (accessed on 17 October 2016).

27. Grullon, G.; Michaely, R.; Swaminathan, B. Are Dividend Changes a Sign of Firm Maturity? J. Bus. 2002, 75, 387-424.

28. Leland, H.E.; Toft, K.B. Optimal capital structure, endogenous bankruptcy, and the term structure of credit spreads. J. Financ. 1996, 51, 987-1019.

29. Hilberink, B.; Rogers, L. Optimal capital structure and endogeneous default. Financ. Stoch. 2002, 6, $237-263$.

30. Décamps, J.P.; Mariotti, T.; Rochet, J.C.; Villeneuve, S. Free cash flow, issuance costs, and stock prices. J. Financ. 2011, 66, 1501-1544.

31. Décamps, J.P.; Villeneuve, S. Rethinking Dynamic Capital Structure Models with Roll-Over Debt. Math. Financ. 2014, 24, 66-96.

32. Miller, M.H.; Modigliani, F. Dividend Policy, Growth, and the Valuation of Shares. J. Bus. 1961, 34, 411-433.

33. Michaely, R.; Thaler, R.H.; Womack, K.L. Price Reactions to Dividend Initiations and Omissions: Overreaction or Drift? J. Financ. 1995, 50, 573-608.

34. Ikenberry, D.; Lakonishok, J.; Vermaelen, T. Market underreaction to open market repurchases. J. Financ. Econ. 1995, 39, 181-208.

35. Fama, E.F.; Babiak, H. Dividend Policy: An Empirical Analysis. J. Am. Stat. Assoc. 1968, 63, 1132-1161.

36. Kumar, P. Shareholder-Manager Conflict and the Information Content of Dividends. Rev. Financ. Stud. 1988, 1, 111-136.

37. Michaely, R.; Roberts, M.R. Dividend Soothing, Agency Costs, and Information Asymmetry: Lessons from the Dividend Policies of Private Firms. Available online: http://jonesgsm.rice.edu/uploadedFiles/ Faculty_and_Research/Academic_Areas/Finance/347Seminar_PDFs/Roberts_090806.pdf (accessed on 19 October 2016).

38. Lee, C.F.; Forbes, S.W. Dividend Policy, Equity Value and Cost of Capital Estimates for the Property and Liability Insurance Industry. J. Risk Insur. 1980, 47, 205-222.

39. Akhigbe, A.; Borde, S.F.; Madura, J. Dividend Policy and Signaling by Insurance Companies. J. Risk Insur. 1993, 60, 413-428.

40. Formisano, R.A. Dividend Decisions and the Structure of the Life Insurance Industry. J. Bus. Res. 1978, 6, 329-344.

41. Lee, C.F.; Forbes, S.W. Income Measures, Ownership, Capacity Ratios and the Dividend Decision of the Non-Life Insurance Industry: Some Empirical Evidence. J. Risk Insur. 1982, 49, 269-289.

42. Tedesco, T. Inside the Fortress: Drama Behind Manulife's Doors. Financial Post. Available online: http:/ / www.financialpost.com/story.html?id=2501883 (accessed on 10 October 2011).

43. Zou, H.; Yang, C.; Wang, M.; Zhu, M. Dividend decisions in the property and liability insurance industry: mutual versus stock companies. Rev. Quant. Financ. Account. 2009, 33, 113-139.

44. Albrecher, H.; Cheung, E.C.K.; Thonhauser, S. Randomized Observation Periods for the Compound Poisson Risk Model: Dividends. Astin Bull. 2011, 41, 654-672. 
45. Avanzi, B.; Cheung, E.C.K.; Wong, B.; Woo, J.K. On a periodic dividend barrier strategy in the dual model with continuous monitoring of solvency. Insur. Math. Econ. 2013, 52, 98-113.

46. Albrecher, H.; Hartinger, J. A Risk Model with Multilayer Dividend Strategy. N. Am. Actuar. J. 2007, 11, 43-64.

47. Lin, X.S.; Sendova, K.P. The compound Poisson risk model with multiple thresholds. Insur. Math. Econ. 2008, 42, 617-627.

48. Avanzi, B.; Pérez, J.L.; Wong, B.; Yamazaki, K. On optimal joint reflective and refractive dividend 369 strategies in spectrally negative Lévy models. Insur. Math. Econ. 2016, in press.

49. Radner, R.; Shepp, L. Risk vs. profit potential: A model for corporate strategy. J. Econ. Dyn. Control 1996, $20,1373-1393$.

50. Højgaard, B.; Taksar, M. Optimal dynamic portfolio selection for a corporation with controllable risk and dividend distribution policy. Quant. Financ. 2004, 4, 315-327.

51. Cadenillas, A.; Choulli, T.; Taksar, M.; Zhang, L. Classical and Impulse Stochastic Control for the Optimization of the Dividend and Risk Policies of an Insurance Firm. Math. Financ. 2006, 16, 181-202.

52. Gerber, H.U.; Shiu, E.S.W. Geometric Brownian Motion Models for Assets and Liabilities: From Pension Funding to Optimal Dividends. N. Am. Actuar. J. 2003, 7, 37-56.

53. Decamps, M.; Schepper, A.D.; Goovaerts, M. Spectral decomposition of optimal asset-liability management. J. Econ. Dyn. Control 2009, 33, 710-724.

54. Avanzi, B.; Henriksen, L.F.B.; Wong, B. Optimal Dividends in an Asset-Liability Surplus Model Under Solvency Considerations. UNSW Australia Business School Research Paper Series 2016ACTL02. Available online: https: / /ssrn.com/abstract=2824887 (accessed on 17 October 2016).

55. Cheung, E.C.K.; Dickson, D.C.M.; Drekic, S. Moments of Discounted Dividends for a Threshold Strategy in the Compound Poisson Risk Model. N. Am. Actuar. J. 2008, 12, 299-318.

56. Albrecher, H.; Cani, A. Risk Theory with Affine Dividend Payment Strategies; Working Paper, 2016.

57. Avanzi, B.; Wong, B. On a mean reverting dividend strategy with Brownian motion. Insur. Math. Econ. 2012, 51, 229-238.

58. Hubalek, F.; Schachermayer, W. Optimizing expected utility of dividend payments for a Brownian risk process and a peculiar nonlinear ODE. Insur. Math. Econ. 2004, 34, 193-225.

59. Thonhauser, S.; Albrecher, H. Optimal Dividend Strategies for a Compound Poisson Process under Transaction Costs and Power Utility. Stoch. Mod. 2011, 27, 120-140.

60. Korn, R.; Menkens, O.; Steffensen, M. Worst-case-optimal dynamic reinsurance for large claims. Eur. Actuar. J. 2012, 2, 21-48.

(c) 2016 by the authors; licensee MDPI, Basel, Switzerland. This article is an open access article distributed under the terms and conditions of the Creative Commons Attribution (CC-BY) license (http://creativecommons.org/licenses/by/4.0/). 


\section{University Library}

\section{- M M I E E R VA A gateway to Melbourne's research publications}

Minerva Access is the Institutional Repository of The University of Melbourne

Author/s:

Avanzi, B;Tu, V;Wong, B

Title:

A Note on Realistic Dividends in Actuarial Surplus Models

Date:

2016-12-01

Citation:

Avanzi, B., Tu, V. \& Wong, B. (2016). A Note on Realistic Dividends in Actuarial Surplus Models. RISKS, 4 (4), https://doi.org/10.3390/risks4040037.

Persistent Link:

http://hdl.handle.net/11343/243003 